\title{
Mantra masyarakat Sasak: Kajian bentuk, fungsi, dan aspek teologi
}

\author{
Agusmana,1,*, Johan Mahyudib,2 \\ Sekolah Tinggi Pariwisata Mataram, Jalan Panji Tilaar No. 99, Mataram, 83115, Indonesia \\ b Universitas Mataram, Jalan Majapahit No. 62, Mataram, 83115, Indonesia \\ 'suganam90@gmail.com; ${ }^{2}$ johanmahyudi82@gmail.com
}

Corresponding Author

\begin{tabular}{l} 
INFO ARTIKEL \\
\hline Sejarah Artikel: \\
Diterima: 5 Juli 2021 \\
Direvisi: 3 September 2021 \\
Disetujui: 16 Septtember 2021 \\
Tersedia Daring: 31 Oktober \\
2021 \\
\hline Kata Kunci: \\
Bentuk \\
Fungsi \\
Teologi \\
Mantra
\end{tabular}

ABSTRAK

Mantra dalam sejumlah literatur dan kajian dijelaskan sebagai ucapan atau perkataan yang memiliki fungsi, bentuk dan bisa mendatangkan kekuatan. Fungsinya bisa sebagai pengobatan, pelindung diri, pemikat, dan sebagainya. Bahasa yang digunakan berbentuk perpaduan antara bahasa daerah dengan kalimat-kalimat islami yang memberikan aspek kesakralan. Namun demikian, terdapat seuatu yang berada di dalam mantra tersebut, yaitu aspek teologi atau pemahaman tentang Tuhan. Pemahaman tentang Tuhan itulah yang sesungguhnya memberikan implikasi terhadap fungsi atau kekuatan mantra tersebut. Dengan demikian, tujuan penelitian ini ialah untuk mendeskripsikan aspek teologi dalam bentuk dan fungsi mantra yang terdapat di dalam kebudayaan masyarakat Sasak. Metode yang digunakan ialah kualitatifetnografi dengan narasumber 2 orang tokoh adat, 2 orang dukun (tukang obat) dan 2 orang pemilik mantra yang diwawancarai untuk memperoleh sejarah serta contoh mantra. Hasil temuan yang diperoleh yaitu mantra ialah ucapan yang memiliki bentuk seperti pantun, tekateki atau puisi dan berfungsi sebagai pengobatan, pelindung diri, berburu dan sebagainya serta bisa menghadirkan kekuatan. Kekuatan yang bisa didatangkan dari mantra tersebut harus didasarkan kepada kepercayaan tentang kekuasaan Allah SWT. Kepercayaan terhadap kekuasaan Allah SWT itulah yang merujuk kepada aspek teologi masyarakat yang tersusun dalam dimensi kepercayaan terhadap Allah SWT, Rasul, takdir, alam gaib dan janji serta ancaman Allah SWT. \section{ABSTRACT}

Keywords:

Form

Function

Theological

Mantra
Mantra in a number of literatures and studies are described as sayings or words that have function, form and can bring power. Its function can be as treatment, self-protection, charm, and so on. The language used is in the form of a blend of regional languages with Islamic sentences that provide a sacred aspect. However, there is something in the mantra, namely the theological aspect or understanding of God. The understanding of God that actually has implications for the function or power of the mantra. Thus, the purpose of this study is to describe the theological aspects in the form and function of mantra contained in the culture of the Sasak people. The method used is qualitative-ethnographic, with 2 traditional leaders, 2 shamans (medicines) and 2 mantra owners being interviewed to obtain the history and examples of mantra. The findings obtained are that mantra are utterances that have forms such as rhymes, riddles or poetry and function as treatment, self-protection, hunting and so on and can bring the power. The power that can be obtained from the mantra must be based on belief in the power of Allah SWT. This belief in the power of Allah SWT refers to the theological aspects of society which are structured in the dimensions of belief in Allah SWT, Rasul, Takdir, the supernatural things and the promises and threats of Allah SWT. 


\section{Pendahuluan}

Mantra dari sudut pandang kebudayaan sangat berhubungan erat dengan ucapan yang mendatangkan kekuatan gaib. Hal ini dapat dirujuk berdasarkan pendapat beberapa ahli yang menjelaskan bahwa mantra dirumuskan dalam perkataan yang bisa mendatangkan kekuatan gaib, jampi, dan pesona (Koentjaraningrat, 2000; Poerwadarminta, 2000; Strauss, 2000). Selain itu, Waluyo (2010) menyebutkan bahwa ciri-ciri mantra meliputi penggunaan diksi yang seksama, adanya pengulangan bunyi yang memperkuat sugesti, menggunakan kata-kata yang tidak lumrah dan dalam pengucapannya secara langsung (dengan nada yang besar) menimbulkan efek bunyi yang magis. Sementara itu, dari definisi leksikal Nurlailah (2006), mengatakan bahwa mantra merupakan jampi-jampi, perkataan atau ucapan yang mengandung kekuatan gaib, dapat menyembuhkan orang, penangkal diri, memikat perempuan dan sebagainya. Penjelasan-penjelasan tersebut memberikan pemahaman bahwa mantra memiliki fungsi pengobatan, penangkal diri, pemikat dan menggunakan struktur kata yang unik, memiliki efek bunyi yang magis serta bisa mendatangkan suatu kekuatan yang bersifat supernatural.

Sementara itu, Sunliensyar (2018), memaparkan bahwa mantra dalam tradisi masyarakat Kerinci memiliki fungsi pemujaan kepada roh moyang, pelindung diri dan sebagai pelaksanaan ritual yang berpola singkritisme antara Hindu-Budha dan Islam. Selain itu juga, dijelaskan bahwa terdapat ayat Al-Quran yang digunakan di dalam perumusan mantra tersebut yang merujuk kepada pola sinkritisme (Alfianoor, 2017; Humaeni, 2014). Berdasarkan pemaparan tersebut, dapat dipahami bahwa masyarakat menggunakan atau mengintegrasikan sejumlah penggalan ayat Al-Quran merepresentasikan pemahaman mengenai ontologis Islam secara mendalam. Selain itu juga, hal ini menunjukkan bahwa masyarakat dari zaman dahulu telah menjadikan Al-Quran sebagai sumber pengembangan ilmu pengetahuan.

Konstruksi kebahasaan mantra antara kalimat biasa dengan kalimat Islami, menunjukkan bahwa masyarakat telah memiliki konsep tentang ilmu agama Islam yang mendalam. Bahkan adanya bentuk bahasa Al-Quran merujuk kepada pemahaman bahwa masyarakat mengambil sumber dari Al-Quran dalam menata bangunan ilmu pengetahuan sebagaimana penjelasan Irvin dan al-Kholidi tentang AlQuran sebagai sumber ilmu pengetahuan (Burhanudin, 2016). Dalam konteks Islam, adanya kalimat-kalimat Islami di dalam mantra itulah yang merepresentasikan aspek kesakralan serta kekuatan gaib yang bisa dihadirkan. Bagi umat Islam konsep hal-hal yang gaib merupakan bagian dari keimanan yang akan bertransformasi di dalam kehidupan beragama (Hikmawati \& Saputra, 2019).

Mantra yang dikombinasikan dengan aspek Islam (adanya kalimat Islami) memberikan kesan kesakralan untuk mendatangkan efek kekuatan gaib tersebut. Mansur (2010) memaparkan bahwa kalimatkalimat yang ada di mantra diyakini dapat melahirkan energi batin bagi orang yang menguasainya. Selain itu juga, Wijayanti (2019) memaparkan mantra memiliki kekuatan yang dapat dilihat dari segi penggunaan kata atau kalimat. Bahkan di luar konteks Indonesia juga, kekuatan yang terdapat di dalam mantra menjadi perhatian yang menarik sebagaimana Fárek \& Horák (2021) memaparkan tentang kekuatan 
metafisika mantra di Eropa dan India. Dengan demikian, dapat dijelaskan bahwa kekuatan-kekuatan yang datang dari mantra dapat dilihat dari kata atau kalimat yang merepresentasikan religiositas seperti penggalan ayat Al-Quran.

Namun demikian, mantra tidak selalu diberikan penilaian yang positif terlebih lagi di tengah kehidupan saat ini. Dewasa ini, mantra jika digunakan oleh seseorang maka tidak jarang akan menimbulkan kesan bahwa orang tersebut masih percaya tahayul, mitos atau primitif. Bahkan secara garis keras, mempercayai mantra dewasa ini sama saja dengan tidak mempercayai kekuasaan Allah SWT. Sebagai contoh kasus, mantra pengobatan dalam praktiknya ditemukan menggunakan doa-doa Islami, namun hal ini tidak sepenuhnya memberikan kesan yang positif terhadap mantra. Bisa saja penggunaan kalimat Islami hanya merujuk kepada embel-embel supaya terkesan Islam dan ini akan ditemukan dalam komentar kehidupan sekarang ini terlebih lagi dalam arus pemikiran fanatisme.

Pernyataan-pernyataan

tersebut

mengenai kesan negatif dari mantra merupakan problematika karena masih melihat mantra secara struktur luarnya saja. Padahal sisi kesakralan dan kekuatan gaib yang terdapat di mantra dalam konteks Islam sangat berhubungan erat dengan kepercayaan kepada Allah SWT dalam bentuk dimensi rukun iman dalam Islam, yaitu mempercayai hal-hal gaib. Ini sesuai dengan yang dikatakan Mulyanto \& Suwatno (2018) tentang kekuatan yang bersumber kepada Tuhan itu merupakan keterhubungan antara manusia dengan aspek kesakralan. Konsep teologi dan kebudayaan selalu terjalin dalam dialog yang terus bertransformasi untuk membentuk hospitalitas kepada manusia (Tari, 2019). Selain itu, hubungan manusia dengan alam (kebudayaan) merupakan teologi kontekstual yang dilakukan untuk menyatakan iman dan mendengar Tuhan (Kleden, 2018). Pemahaman tentang Tuhan jika telah dimiliki secara utuh maka akan mengimplikasikan penyerahan diri secara sadar. Hal ini bisa disejajarkan dengan defenisi pasrah atau berserah diri kepada Tuhan seutuhnya sebagai dasar dari beragama (Mansur \& Saputra, 2019; Sopandi \& Taofan, 2019). Iskandar (2017) memaparkan bahwa teologi tentang ilmu dan pemahaman manusia terhada agama bersifat esoteris. Ilmu tentang Tuhan tersebut akan membentuk sikap kepecayaan di dalam konteks Islam yang berhubungan erat dengan rukun iman sebagaimana Rifa'i yang menjabarkannya dalam bentuk konsep rukun iman dalam Islam (Makmun, 2018). Mantra yang berkaitan dengan hal gaib atau sakral sejatinya merujuk kepada konsep keislaman tentang teologi secara mendalam dan inilah yang perlu diperdalam melalui pemahaman yang mendalam dan filosofis.

Oleh karena itu, penelitian ini perlu dilakukan untuk mendeskripsikan pemahaman mengenai Tuhan yang ada di dalam mantra tersebut dari sisi bentuk dan fungsi mantra tersebut. Selain itu, menjelaskan bahwa mantra ialah media atau perantara dan bukan hal yang diyakini karena yang wajib diyakini ialah kekuasan Allah SWT sebagai penguasa segala semesta. Terlebih lagi penelitian tentang mantra di masyarakat Sasak masih belum merunut tentang pemahaman mengenai Tuhan (aspek teologi) di dalam mantra. Sebagaimana yang tampak pada penelitian Fakihuddin \& Sarwadi (2019) mengkaji mantra Sasak dari sisi klasifikasi, fungsi dan, tata aturan penggunaannya. Penelitian tersebut menujukkan bahwa terdapat mantra yang digunakan untuk menyembuhkan penyakit, pelindung diri dan sebagainya serta dalam penggunaanya secara umum tidak membutuhkan sejumlah syarat atau aturan yang ketat. Dari sisi makna mantra, Idham (2019) menemukan makna asosiatif yang menunjukkan bahwa terdapat maknamakna terhadap makhluk lain, simbol mistis, bahkan simbol Islami yang mengarah kepada aspek kepercayaan dalam keimanan.

Dengan demikian, kajian ini diharapkan mendapatkan pemahaman tentang ada yang memberikan kekuatan gaib atau merujuk kepada aspek teologi tersebut. Dalam hal ini, 
yang dibutuhkan ialah hermeneutika untuk mengungkapkan kata-kata, menjelaskan dan menerjemahkannya ke dalam pemahaman (Palmer, 2003). Hermeneutika merujuk kepada pertumbuhan secara aspek historis, kesejarahan makna-maknanya, tata bahasa, dan sintaksisnya sehingga bahasa muncul sebagai bentuk-bentuk varian logika pengalaman, hakikat, termasuk pengalaman historis atau pengalaman supernatural (Mulyono, 2013). Hal inilah yang memungkinkan dijadikan sebagai cara untuk menemukan ada yang berada di balik kekuatan mantra yang hadir sehingga kalimat Islami seperti basmalah, nama Allah, nabi (yang merujuk ke aspek keIslaman) dalam mantra dapat dipahami secara mendalam dan filosofis. Selain itu, ditekankan mengantarai masa lalu dan masa kini antara yang asing dan yang lazim sebagai sebuah bagian dalam proses memahami dan tentunya berada dalam konteks pembaca dengan teks itu sendiri (Gadamer, 2004; Iyubenu, 2015; Warnke, 1987). Hal ini sangat dibutuhkan untuk menemukan segala substansinya baik itu bentuk atau klasifikasi, fungsi serta yang terpenting ialah bangunan pengetahuan mengenai Tuhan di dalam mantra tersebut dapat dipahami dengan baik sebagai rujukan mengembangkan kehidupan berbasis karakter religius (Anggraeni et al., 2019; Hastuti, 2018; Maryani, 2011). Lebih dari itu, mantra telah menjadi produk budaya dan dimiliki oleh berbagai lapisan masyarakat. Hal ini merujuk kepada rasa kebersamaan untuk menjaga, memahami, dan mengaplikasikan nilai dan pemahaman dari suatu budaya di dalam kehidupan sebagai pola kehidupan bersama (Bakhtiar, 2014; Ritzer, 2002).

\section{Metode}

Penelitian ini mengunakan pendekatan kualitatif karena didasarkan kepada kriteria yang mencakup objek kajian, yaitu berupa bahasa (kalimat) mantra. Sementara itu, jenis penelitian ini menggunakan etnografi yang merujuk kepada bahasa, adat atau tradisi, simbol atau benda (Creswel, 2013;
Haris, 2001; Spradley, 1979). Penelitian ini dilakukan di Lombok Tengah, Kecamatan Jonggat, Bonjeruk dengan turun ke lapangan untuk mewawancarai tokoh adat (2 orang), tukang obat (2 orang) dan pawang ( 2 orang). Waktu pelaksanannya antara 4-10 Maret 2021. Selain itu, digunakan juga teknik catat untuk mencatat contoh kalimat mantra tersebut.

Sementara itu, wujud data penelitian ini adalah kalimat-kalimat mantra yang menunjukkan pola struktur penggunaan bahasa Al-Quran (perpaduan dengan bahasa daerah Sasak) pada awal kalimat, tengah dan akhir. Semua data tersebut diperoleh dari hasil wawancara sejumlah narasumber yang disertai teknik catat mengenai objek kajian, yaitu mantra. Data tersebut dianalisis dengan melihat struktur kalimat untuk mendapatkan bentuk mantra, kemudian kalimat-kalimat mantra tersebut dianalisis dari sisi fungsionalitasnya untuk mendapatkan fungsi mantra serta melakukan interpretasi diksi utama yang merujuk kepada maknamakna ketuhanan untuk mendapatkan aspek teologisnya dalam konsep dialektika teks dengan pembaca.

\section{Hasil dan Pembahasan}

Berdasarkan hasil temuan yang diperoleh di lapangan, yaitu hasil wawancara dengan 2 orang tokoh adat (Amaq Ila 58 tahun dan Amaq Ipul 52 tahun) tanggal 5 Maret 2021 pukul 20.00-22.15 WIB ditemukan bahwa mantra dalam bahasa Sasak dilafalkan menjadi montorə/məntro yang berarti ucapan yang bisa mendatangkan kekuatan. Mantra telah lama ada di masyarakat Sasak sebelum abad XVI. Mantra pada zaman dahulu digunakan sebagai media untuk melindungi diri dan pengobatan yang bisa berbentuk pantun, teka-teki, atau puisi. Selain itu, mantra berhubungan dengan ilmu atau kekuatan yang baik dan berbeda dengan ilmu hitam yang dalam istilah Sasak dinamakan $s E h E r$ (sihir). Dalam kaitannya dengan aturan pemakaian, terdapat mantra secara umum tanpa adanya syarat, mantra berdasarkan keturunan biasanya terdapat syarat yang 
ringan dan mantra perorangan yang syaratnya khusus. Syarat tersebut biasanya merujuk kepada berpuasa, solat sunah, dan zikir.

Kalimat mantra juga bisa menggunakan bahasa daerah (Sasak), perpaduan antara bahasa Sasak dan Al-Quran (nama Allah, Rasul dan sebagainya) atau kalimat dalam Al-Quran. Penggunaan sebagian ayat AlQuran atau penyebutan nama Allah dan sebagainya telah lama ada sebagai bentuk proses manifestasi pemahaman tentang Tuhan sebagai pemiliki segala sesuatu. Misalnya, kata Laa Ilaaha Illallaah dalam penutup mantra harus dipahami makna, fungsi tujuan, dan refleksinya di dalam diri atau aspek ontologis hingga kepada aksiologinya berdasarkan pendekatan tasawuf (tarekat) sehingga dapat memberikan hasil berupa kekuatan. Penggunaan atribut Islami tersebut memiliki hubungan terhadap konsep kepercayaan tunggal kepada Allah SWT tiada lain selain Allah sehingga konsep teologi tersebut dapat diikrarkan dengan hati, diucapkan dengan lisan, dan diamalkan dalam tindakan. Dengan demikian, jika telah diserahkan hanya kepada Allah, maka segala bentuk tindakan, hal atau peristiwa tidak akan bisa terjadi tanpa izin dari Allah SWT. Biasanya orang yang memiliki mantra adalah orang yang mempunyai pikiran, pemahaman mendalam mengenai hakikat kosmik baik dalam diri maupun di luar diri. Sebagai tambahan, kata Laa Ilaha Illallah pun bisa menjadi mantra agar bisa berjalan di atas air, tapi dengan konsep yang telah dijelaskan tersebut.

Sementara itu, wawancara kedua ditujukan kepada 2 orang tukang obat (Masna 39 tahun dan Oaq Oe 48 tahun) tanggal 6 maret 2021 pukul 16.00 WIB. Kedua narasumber memaparkan bahwa mantra bisa dikatakan sebagai kata kunci untuk membuka sesuatu. Ibarat pintu yang telah dikunci dan dibuka maka segala sesuatu bisa dimasukkan, dikeluarkan, dibersihkan, dan sebagainya. Kedua narasumber juga menyatakan bahwa terdapat konsep Islam di dalam mantra karena penggunaan kalimat Islami serta yang paling penting dari mantra adalah aspek kepercayaan yang benar-benar tinggi. Tidak ada segala sesuatu yang berfungsi sakral jika tdk dilandaskan kepada aspek kepercayaan yang tinggi.

Hasil wawancara ketiga kepada 2 orang yang memiliki mantra (Ardi 42 tahun dan Samsul 41 tahun) tanggal 9 Maret 2021 pukul 09.00 WIB menuturkan bahwa mantra banyak macamnya, yaitu mantra kebal, pemikat, pengasih, pengobatan, pengusir binatang buas, pelindung diri, mantra mancing dan sebagainya. Di dalam kalimatnya, terdapat kalimat Islami. Misalnya basmalah sebagai kalimat pembuka mantra. Hal ini menunjukkan bahwa segala sesuatu tercipta atau ada dari dan berkat dengan nama Allah semata. Jika segala sesuatu dikembalikan hanya kepada Allah yang berkuasa, maka segala sesuatu itu akan tunduk dan patuh kepada Allah. Ini merupakan konsep pengetahuan tentang zat Allah yang ada di dalam kata-kata khususnya kata Islami di dalam mantra.

Selain itu, narasumber ketiga tersebut mengatakan bahwa mantra yang telah dipahami dengan baik harus berhati-hati di dalam menggunakannya supaya tidak menimbulkan mudarat kepada orang lain. Mantra lebih baik digunakan jika dalam hal mendesak. Kalimat mantra juga tidak harus diperoleh dari bertapa atau meminta karena secara personal bisa membuat mantra tersendiri, tetapi dengan catatan setiap kata, struktur kalimat, makna serta hakikatnya dapat dipahami secara mendalam dan filosofis dalam konteks ilmu tasawuf. Berikut contoh mantra yang ada di masyarakat Sasak.

\section{A. Mantra Pengobatan}

1. muq daun pacé

ketabuan léq tengaq bangket

dengan maté

beketuan léq semanget

berkat

Laailaaha illallaah,

puh 
(Oaq Oe 59 tahun, 6 maret 2021)

2. Bismillaahirrohmaanirrohiim

batu kumbung batu putéq

aku tundung sétan uléq

(Oaq Oe 59 tahun, 6 maret 2021)

\section{B. Mantra Adigdaya}

1. Bismillaahirrohmaanirrohiim

tolangku menjadi besi

uratku menjadi geleng

kulitku menjadi temage

bulungku menjadi jarum

matengku menjadi timah

berkat kalimah

Laailaahaillallaah

Muhammadarrosuulullaah

(Amaq Ila 58 tahun, tanggal 5 Maret 2021)

2. sut maksud mantra malakut

turlemes tau kejarian

tanah putih manusia kejarian aiq

jagaq isiq julu jagaq isiq muri

jagaq isiq kiri jagaq isiq kanan

berkat Laa Ilaaha Illallaah

Muhammadarrosuulullaah

(Amaq Ipul 49 tahun, 5 Maret 2021)

3. Bismillaahirrohmaanirrohiim

inaq léq julu

amaq léq mudi

berkat Laa Ilaaha Illallaah

(Amaq Ila 58 tahun, tanggal 5 Maret 2021)

4. adam asal tanaq

kembali jari tanaq

dan kembali jari adam

berkat Laa Ilaaha Illallaah

Muhammadarrosuulullaah

(Amaq Ipul 52 tahun, 5 Maret 2021)

\section{Mantra Pemikat}

kubalik galengku kubalik simbutku adéqne kebalik kebelah angenne léq aku

wahai ...(nama seseorang yang dituju)

berkat Laa Ilaha Illallah

Muhammadarrosulullah
(Ardi 42 tahun, tanggal 9 Maret 2021)

\section{Mantra Berburu (mancing ikan)}

1. Bismillaahi Innahu Min Sulaiman

Bismillaah

\section{Berekat Laailaahaillallaah}

(Ardi 42 tahun, tanggal 9 Maret 2021)

2. pok porot teloq beléncek

kamu morot aku nyéntek

(Ardi 42 tahun, tanggal 9 Maret 2021)

\subsection{Bentuk Mantra}

Berdasarkan hasil wawancara beberapa narasumber di atas, dapat dijelaskan bahwa mantra di dalam kebudayaan masyarakat Sasak disebut dengan istilah məntərə/məntro yang mendatangkan kekuatan gaib. Lawan dari mantra disebut dengan istilah $s E h E r$ (sihir) yang merujuk kepada ilmu gaib yang digunakan untuk mencelakai seseorang. Ini sesuai dengan pernyataan narasumber yang telah diwawancai. Berdasarkan bentuknya, mantra bisa berbentuk puisi, pantun, atau teka-teki.

Mantra berbentuk puisi tampak pada mantra adigdaya poin 1 dan $\underline{2}$. Kriteria dikatakan sebagai puisi ialah terdiri atas sejumlah bait, menggunakan perpaduan kata-kata yang tidak sama dengan bahasa sehari-hari dan sarat dengan makna. Misalnya kalimat tolangku menjadi besi, uratku menjadi geleng (tulangku menjadi besi, uratku menjadi roda) yang dalam konsep pemahaman secara umum tidak mudah dipahami karena berbentuk kiasan.

Mantra yang berbentuk teka-teki tampak pada mantra adigdaya poin 3 dan $\underline{4}$. Kriteria yang menunjukkan bentuk teka-teki karena bersifat pertanyaan, misalnya pada kalimat Adam asal tanaq, Kembali jari tanaq, Dan kembali jari adam (adam asalnya tanah, kembali menjadi tanah, dan kembali menjadi adam). Contoh yang lain ialah Inaq leq julu, Amaq leq muri (Ibu di depan, Ayah di belakang). Kalimat mantra tersebut merujuk kepada pertanyaan secara tidak langsung tentang hakikat atau siapakah sebenarnya manusia sebagai keturunan Adam tersebut. Sementara kalimat Inaq leq 
julu, Amaq leq muri (Ibu di depan, Ayah di belakang) merujuk kepada pertanyaan siapakah yang tengah dari posisi kedua orang tua tersebut, yaitu Ibu di depan dan Ayah di belakang. Kriteria mantra yang berbentuk pantun tersebut sesuai dengan yang dikatakan narasumber 2 tokoh adat.

Sementara itu, mantra berbentuk pantun dintunjukkan dengan adanya pola sampiranisi. Kriteria yang menunjukkan pantun ialah adanya kesesuaian bunyi kata pada sampiran dan isi serta tidak ada batasan mengenai jumlah barisnya. Mantra yang berbentuk pantun bisa dilihat pada mantra pengobatan (poin 1 dan 2) serta mantra berburu/mancing. Misalnya, kalimat mantra pok porot teloq beléncek, kamu morot aku nyéntek yang kalimat pertama adalah sampiran dan kalimat kedua adalah isi. Hal ini sama polanya dengan bentuk pantun dalam bahasa Indonesia seperti jika ada sumur di ladang boleh kita menumpang mandi, jika ada umur panjang boleh kita berjumpa lagi. Mantra yang berbentuk pantun ini merujuk kepada pemaparan yang disampaikan oleh narasumber.

Dengan demikian, dapat dijelaskan mantra masyarakat Sasak bisa berbentuk seperti puisi, pantun dan teka-teki yang kesemuanya itu menunjukkan adnaya aspek keindahan atau harmonisasi bunyi (perhatikan setiap huruf yang ditebalkan pada contoh mantra di atas). Hal ini dapat dipertegas dengan pernyataan bahwa ciriciri mantra meliputi penggunaan diksi yang seksama, adanya pengulangan bunyi yang memperkuat sugesti, menggunakan katakata yang tidak lumrah dan dalam pengucapannya secara langsung (dengan nada yang besar) menimbulkan efek bunyi yang magis (Waluyo, 2010). Selain itu juga, diksi pada conoth mantra berbentuk puisi, sut maksud mantra malakut, yaitu kata malakut merujuk kepada kata yang dalam konsep pemahaman berada dalam konteks religius karena menangkut tentang tingkatan alam dala ilmu tasawuf. Hal tersebut menimbulkan kesan magis sebagaimana yang dikatakan oleh Wijayanti (2019).

\subsection{Aspek Fungsi Mantra}

Aspek fungsi mantra bagi masyarakat Sasak sebagaimana yang diperoleh dari wawancara ialah untuk pengobatan, adigdaya, berburu atau pemikat. Fungsi mantra tidak bisa berfokus kepada satu sisi saja, tetapi fungsinya sangat bergantung kepada konteks.

Fungsi mantra sebagai pengobatan merujuk kepada ucapan yang berhubungan dengan sesuatu yang gaib (bersifat negatif) sehingga mantra pengobatan ini sering menggunakan perpaduan ayat atau kalimat Islami, seperti basmalah. Kalimat basmalah digunakan karena merujuk kepada segala sesuatu penyakit mengenai asal usul hanya akan kembali dan berasal dari Allah SWT. Mantra dengan fungsi ini sangat sering bahkan sampai sekarang masih banyak yang digunakan di kalangan masyarakat. Pengobatan penyakit melalui media mantra yang dibacakan oleh dukun sering disebut dengan istilah oat Sasak (obat Sasak). Biasanya di saat penggunaan mantra sebagai media pengobatan, disertai juga dengan racikan bahan alami sebagai pelengkap seperti sirih, kapur, pinang bahkan air gelas (botol) yang dibacakan mantra.

Fungsi mantra sebagai adigdaya merujuk kepada bentuk perlindungan diri. Sebagaimana penjelasan narasumber, mantra ini digunakan pada saat merasa sesuatu yang tidak baik akan menimpa. Tidak ada syarat yang harus disediakan saat pengapklikasian mantra ini, tetapi yang sering terjadi ialah saat waktu penerimaan mantra pertama kali (diberikan) sering dipersyaratkan puasa atau salat sunah.

Mantra yang difungsikan sebagai pemikat (pelet) biasanya digunakan oleh remaja. Mantra ini didapatkan dengan cara meminta dari dukun langsung dan cara pengaplikasiannya seperti yang tampak pada kalimat mantra. Misalnya kubalik galengku kubalik simbutku, adéqne kebalik kebelah angenne léq aku, wahai ... (nama seseorang yang dituju) ... (kubalik bantalku, kubalik selimutku, supaya jatuh bangun hatinya kepadaku, yang dilanjutkan dengan menyebut nama seseorang yang dituju). 
Namun, ada juga mantra pemikat yang dilakukan oleh dukun secara langsung. Implikasi dari mantra pemikat ini tidak memberikan jaminan keberlangsungan, artinya mantra pemikat ini memiliki masa atau batas waktu sehingga jika seorang perempuan terkena dan mantra tersebut telah habis masanya maka perempuan tersebut akan kembali kepada keadaan sebelumnya.

Sementara itu, mantra berburu difungsikan dengan tujuan untuk mendapatkan keberuntungan yang lebih. Syarat dari mantra ini tidak ada yang bersifat berat karena biasanya saat melakukan tindakan mantra ini langsung dibaca. Bisanya juga, mantra ini digunakan saat sendiri dalam artian tidak ada orang lain yang ikut ambil bagian, misalnya saat mancing sendiri. Hal ini sesuai dengan penjelasan 2 narasumber pemiliki mantra tentang penggunaan mantra yang didasari dengan kehati-hatian supaya tidak merugikan orang lain.

Dengan demikian, berdasarkan uraian tentang fungsi mantra di atas, dapat dijelaskan bahwa mantra masarakat Sasak memiliki sejumlah fungsi. Hal ini diperkuat oleh pernyataan mantra tersebut memiliki berbagai bentuk dan fungsi mendatangkan kekuatan gaib (Koentjaraningrat, 2000; Poerwadarminta, 2000; Strauss, 2000). Selain itu, fungsi-fungsi yang dihadirkan juga besrifat gaib atau kekuatan di luar logika manusia. Hal ini dipertegas dari hasil beberapa penelitian yang memaparkan tentang fungsi dari kekuatan mantra tersebut (Alfianoor, 2017; Fárek \& Horák, 2021; Humaeni, 2014; Mansur, 2010; Nurlailah, 2006; Sunliensyar, 2018; Wijayanti, 2019).

\subsection{Aspek Teologi Mantra}

Aspek teologi yang ada di dalam mantra ini merujuk kepada kepercayaan terhadap Allah SWT. Kepercayaan ini harus benarbenar mutlak, absolut atau di atas keyakinan secara umum. Bangunan teologi masyarakat Sasak tersusun dari pondasi berupa kalimat syahadat, yaitu Muhammad yang mengakui tiada Tuhan selain Allah SWT dan Allah SWT mengakui Muhammad sebagai utusan-
Nya dan di manusialah semuanya termanfestasikan. Inilah pondasi inti sehingga segala bentuk yang ada di atasnya merupakan manifestasi penghayatan yang mendalam baik secara vertikal maupun horizontal. Selain itu, masyarakat Sasak dikenal dengan sebutuan 1000 masjid dan ini merupakan representasi dari sebutan tersebut berupa pengahayatan mendalam tentang hakikat Allah SWT. Pemahaman mengenai Allah SWT akan merujuk kepada aspek rukun iman dalam Islam sehingga teologi masyarakat Sasak tersusun dalam dimensi-dimensi rukun iman. Berikut pemaparan dari masing-masing aspek teologi tersebut.

Pertama kepercayaan terhadap Allah SWT. Hal ini tampak pada pemikiran, sikap dan representasi di dalam mantra. Pemikiran tercermin pada kepercayaan bahwa hanya Allah SWT yang kekal, penentu sekaligus enguasa segala alam mikro-makro kosmos atau alam yang tampak dan tidak tampak. Sebagaimana yang dikatakan narasumber, iman terhadap Allah SWT sebagian orang merupakan harga mati dan tidak bisa digantikan. Hal ini tampak pada penggunaan basmalah, tahli, atau penggalan ayat AlQuran.

Basmalah sebagai pembuka kalimat mantra menunjukkan adanya pemahaman bahwa segala sesuatu dimulai dengan asma Allah atau dengan kata lain realitas adalah pancaran dari asma Allah SWT, yaitu Bismillahi ... (Dengan menyebut nama Allah ...). Sementara itu, penggunaan kalimat Laa Ilaaha Illallaah (secara lengkap atau sebagian) merepresentasikan pemahaman tauhid masyarakat bahwa dasar segala sesuatu ialah pengakuan tiada Tuhan selain Allah sebagai penguasa. Kalimat basamalah mengafirmasikan bahwa segala alam realitas ini dimulai atau diawali dari asma Allah sesuai dengan arti kata Bismillaahi, yaitu dengan menyebut nama Allah dan tahlil merujuk kepada muara atau akhir segala sesuatu hanya kepada Allah SWT. Hal ini merupakan penegasan tentang men-Tauhidkan Allah SWT sebagai penguasa hakiki, tunggal sekaligus sebagai penguasa 
kesemestaan yang akan berimplikasi terhadap berserah diri secara utuh kepada Allah SWT dalam segala hal sehingga dalam mantra pengobatan yang dibuka dengan basmalah dan ditutup dengan tahlil merujuk kepada penyerahan segala sebab penyakit dan kesembuhan hanya kepada Allah SWT. Bahkan dikatakan juga bahwa orang yang menguasai ilmu Allah SWT di atas keyakinan tertinggi cukup dengan melafaskan asma Allah saja ia mampu menyebuhkan berbagai penyakit. Hal ini juga menunjukkan suatu yang dikatakan sebagai zat yang $a d a$ dalam segala keberadaan dan ini sesuai dengan pola penjelasan tentang tafsir hermeneutika dalam merunut makna historis menuju aspek religiusitas antara teks dengan konteks sekarang (Gadamer, 2004; Iyubenu, 2015; Mulyono, 2013; Warnke, 1987).

Kedua kepercayaan terhadap Rasul. Hal ini tampak pada penggunaan atau penyebutan Nabi Muhammad SAW sebagai utusan Allah SWT (dalam kalimat Tahlil). Nabi Muhammad dalam konsep pemahaman adalah Nur yang memancarkan realitas kehidupan atau dengan kata lain bahwa dunia ini adalah bangunan yang yang berbentuk pohon Muhammad SAW. Dengan demikian, ketika segala sesuatu dilandaskan kepada Nur Muhammad maka segala sesuatu dalam alam realitas dunia akan tunduk dan patuh kepada Nur Muhammad. Selain itu, terdapat juga penyebuatan nama Nabi, misalnya Sulaiman AS yang tampak pada mantra berburu (mancing). Konsep pemahamannya ialah Sulaiman AS adalah Nabi yang mampu berkomunikasi dengan binatang atau bisa dikatakan binatang tunduk kepada Sulaiman sebagai wujud wahyu dari Allah SWT. Dengan demikian, nama Nabi Sulaiman disebut dalam kalimat mantra sebagai permintaan kepada pengarah pasukan (binatang) tersebut.

Ketiga kepercayaan terhadap janji dan ancaman Allah SWT. Aspek ini merujuk kepada gabungan antara kitab-kitab Allah dan hari akhir (tentang konsekuensi dari segala tindakan manusia). Kitab-kitab Allah khususnya Al-Quran merujuk kepada kekuasaan Allah SWT yang wajib diimani dengan keyakinan tinggi dan barang siapa yang ingkar sungguh akan mendapatkan balasan yang sesuai. Konsep ini bisa dirunut dengan kepercayaan terhadap mantra. Namun, yang dipercayai bukanlah orang yang membaca mantra, tidak juga kalimat mantra atau kekuatan yang hadir, melainkan yang wajib dipercayai ialah Allah SWT sebagai penguasa atas segalanya untuk memberikan fungsi atau kekuatan dari mantra tersebut. Hal ini akan berkorelasi dengan pernyataan bahwa orang yang menguasai mantra biasanya adalah orang yang memiliki pemahaman dan keyakinan sangat tinggi mengenai Allah SWT sebagaimana pemaparan narasumber 2 orang tokoh adat tersebut.

Keempat kepercayaan terhadap takdir. Takdir merujuk kepada ketetapan yang telah diberlakukan oleh Allah SWT. Konsep pemahaman takdir yang terdapat di dalam mantra ialah merujuk kepada efek atau implikasi dari fungsi mantra. Jika mantra tersebut ditakdirkan oleh Allah SWT bisa membuat orang sehat maka akan berhasil demikian juga sebaliknya sehingga sering ditemukan bahwa mantra seseorang hanya bisa berfungsi satu kali bahkan jika Allah SWT tidak memberikan takdir untuk sembuh maka mantra sesakral apapun tidak akan pernah berfungsi (lihat juga penjelasan mengenai fungsi mantra pemikat di atas). Dengan demikian, takdir merujuk kepada apa yang ditimbulkan dari mantra tersebut bukanlah implikasi dari ketaatan atau pemahaman seseorang tentang kuasa Allah SWT, namun merujuk kepada Allah sebagai penentu segala sesuatu dalam ketetapanNya.

Terakhir yaitu kepercayaan terhadap hal-hal gaib. Hal-hal gaib merujuk kepada segala sesuatu yang berada di luar logika manusia umum atau bersifat metafisika. Dalam hal ini, kekuatan mantra berada dalam ranah gaib atau metafisika sehingga jika tidak dilandaskan dengan percayaan yang tinggi dengan hal-hal gaib maka akan mental begitu saja. Konsep pemahaman masyarakat Sasak tentang hal-hal gaib 
merujuk kepada konsep alam kehidupan dan makhluk ciptaan Allah yang lain yang harus dijaga keseimbangan relasinya dengan kehidupan manusia. Sebagai contoh ketika seseorang dirasuki makhluk halus, maka segala tindakan seseorang itu berada di luar logika manusia. Jadi, hal-hal gaib yang diyakini tersebut harus dijaga keseimbangannya dengan sistem kehidupan manusia. Sebagai tambahan juga, di dalam Al-Quran surat al-Baqarah ayat 2 dikatakan orang-orang yang beriman kepada hal-hal gaib ... (Allaziina yuqminuuna bilghoibi ...). Kata ghoibi dalam hal ini merujuk kepada segala sesuatu yang berada di luar logika. Hal-hal gaib tersebut bukan merujuk kepada sesuatu seperti kekuatan jahat atau setan, melainkan merujuk kepada konsep sifat dari kuasa Allah SWT karena yang ada itu hanya Allah SWT sesuai dengan konsep ada di dalam hermeneutika (Palmer, 2003).

Berdasarkan uraian di atas, dapat dijelaskan bahwa konsep teologi masyarakat Sasak merujuk kepada konsep rukun iman. Hal ini sesuai dengan pernyataan Rifa'i yang menjabarkannya teologi dalam bentuk konsep rukun iman dalam islam (Makmun, 2018). Selain itu, penggunaan kalimat islami pada mantra tersebut menunjukkan aspek transformasi tentang teologi dalam berbagai relasinya (Hikmawati \& Saputra, 2019; Tari, 2019). Dari sisi sikap yang ditunjukkan di dalam mantra tersebut, hal ini menjelaskan bahwa masyarakat Sasak berseran diri seutuhnya kepada Allah SWT sebagai Maha Penguasa. Hal ini sesuai dengan pernyataan (Mansur \& Saputra, 2019; Sopandi \& Taofan, 2019) tentang konsep berserah diri secara sadar sebagai implikasi dari teologi yang mendalam.

Dengan demikian, mantra di dalam masyarakat Sasak ditemukan aspek tentang konsep teologi atau pemahaman tentang Tuhan dan segala manifestasi-Nya. Konsep teologi tersebut dapat dilihat secara langsung dari penggunaan kalimat Basamalah, Tahlil atau penggalan ayat Al-Qur'an yang lain yang disertai dengan pemahaman secara mendalam. Penggunaan basmalah, tahlil atau penggalan ayat Al-Quran lainnya dalam mantra tersebut bisa dijelaskan sebagai bentuk refleksi pemahaman masyarakat tentang Allah SWT dalam berbagai bentuk manifestasi kesemestaan yang dilingkupiNya yang hanya dimuarakan kepada Allah SWT semata. Selain itu juga, hal ini memberikan tambahan mengenai konsep mantra masyarakat Sasak, yaitu di sisi lain mengandung konsep teologi yang mendalam selain memiliki bentuk, fungsi, klasifikasi dan makna sebagaimana yang dijelaskan oleh Fakihuddin \& Sarwadi (2019) dan Idham (2019) tentang makna mantra masyarakat Sasak.

\section{Kesimpulan}

Berdasarkan hasil pembahasan tentang mantra di atas, dapat diberikan simpulan bahwa mantra yang terdapat di dalam kebudayaan Sasak ialah produk kebudayaan dalam bentuk ucapan dengan perpaduan bahasa daerah dan kalimat Islami yang memiliki berbagai fungsi serta mengandung kekuatan gaib. Fungsinya ialah untuk pengobatan, pelindung diri, adigdaya, berburu, dan sebagainya. Bentuknya bisa seperti pantun karena memiliki sampiran dan isi, teka-teki atau puisi yang memiliki korespondensi bunyi. Dari sisi bahasanya, terdapat perpaduan kalimat Islami dengan bahasa daerah. Kalimat Islami yang ditemukan ialah basmalah, tahlil, nama nabi atau penggalan ayat Al-Qur'an. Penggunaan kalimat Islami tersebut menunjukkan adanya konsep teologi masyarakat yang disertai dengan pemahaman tentang ontologis, epistemologis dan aksiologisnya. Konsep teologi dalam mantra tersebut tercermin dalam dimensi-dimensi keimanan, yaitu percaya kepada Allah SWT (dalam segala hal, yaitu Allah sebagai penguasa atas semesta), percaya terhadap rasul, janji dan ancaman Allah SWT, takdir dan hal-hal gaib.

Mantra harus dilihat dari sisi yang lebih dalam lagi, yaitu dari kerangka pemahaman tentang kepercayaan terhadap kuasa Allah SWT secara mendalam dan filosofis sehingga mantra beserta segala substansi bisa dijadikan sebagai acuan membangun peradaban yang religius berdasarkan 
kearifan-kearifan lokal. Mantra sebagai produk kebudayaan bukanlah produk yang bertentangan dengan nilai-nilai keagaaman (Islam), namun penuh dengan konsep pemahaman Tuhan beserta manifestasi-Nya yang disimbolkan, dipadatkan dan direfleksikan dalam bahasa khususnya di dalam mantra. Sebagai tambahan, kajiankajian mengenai budaya daerah seperti mantra dan sebagainya perlu diberikan perhatian lebih dan serius karena di dalam budaya-budaya daerah tersebut tersimpan berbagai macam substansi (nilai, fungsi, pengetahun dan sebagainya) yang menjadi ruh pemersatu seluruh budaya di nusantara ini. Selain itu, menyangkut tradisi daerah khususnya mantra perlu dihidupkan kembali aspek kesakralannya dengan benar sesuai aturannya sehingga mantra bisa menjadi alternatif bagi masyarakat untuk memberikan solusi di dalam kompleksitas situasi kehidupan saat ini, misalnya mantra pengobatan sebagai media pengobatan di tengah menjamurnya berbagai macam jenis penyakit.

\section{Daftar Pustaka}

Alfianoor, A. (2017). Ayat Al-Qur'an dalam Mantra Banjar. NALAR: Jurnal Peradaban Dan Pemikiran Islam, 1(1), 27.

https://doi.org/10.23971/njppi.v1i1.900

Anggraeni, D., Hakam, A., Mardhiah, I., \& Lubis, Z. (2019). Membangun Peradaban Bangsa Melalui Religiusitas Berbasis Budaya Lokal. Jurnal Online Studi Al-Qur'an, 15(1), 95-116. https://doi.org/10.21009/JSQ.015.1.05

Bakhtiar, A. (2014). Filsafat Ilmu (Revisi). Grafindo.

Burhanudin, U. (2016). Landasan Metodologis Teologi Pendidikan Islam. Jurnal Pendidikan Islam, 27(2), 255. https://doi.org/10.15575/jpi.v27i2.510

Creswel, J. W. (2013). Penelitian Kualitatif dan Desain Riset. Pustaka Pelajar.

Fakihuddin, L., \& Sarwadi, G. (2019).
Mantra Sasak: Klasifikasi, Fungsi, dan Penggunaannya oleh Masyarakat Desa Ganggelang. Jubindo: Jurnal Ilmu Pendidikan Bahasa Dan Sastra Indonesia, $\quad 4(1)$. https://doi.org/10.32938/jbi.v4i1.148

Fárek, M., \& Horák, P. (2021). Magic between Europe and India: On mantras, coercion of gods, and the limits of current debates. Religions, 12(2). https://doi.org/10.3390/rel12020087

Gadamer, H. . (2004). Kebenaran dan metode - Google Books. Pustaka Pelajar. https://www.google.co.id/books/edition /Kebenaran_dan_metode/YbIiDQEAC AAJ?hl=id

Haris, M. (2001). The Rise of Anthropological Theory - Google Books. Almatamira Press. https://www.google.co.id/books/edition /The_Rise_of_Anthropological_Theory /yUUYN3X18dwC?hl=id\&gbpv $=1 \& d$ $\mathrm{q}=$ The + Rise + of + Anthropological+The ory:+A+History+of + Theories + of + Cult ure \&printsec $=$ frontcover

Hastuti, H. B. P. (2018). Nilai Kesantunan dalam Mantra Meoli. Suar Betang, 12(2), 151. https://doi.org/10.26499/surbet.v12i2.2 7

Hikmawati, R., \& Saputra, M. (2019). Manifestasi Keimanan Akan Makhluk Ghaib (Jin) dalam Kehidupan Beragama Umat Islam (Studi Kasus ekspresi beragama Ormas Nahdlatul 'Ulama dan Persatuan Islam di Kota Bandung). Jaqfi: Jurnal Aqidah Dan Filsafat Islam, 4(2), 131-155. https://doi.org/10.15575/jaqfi.v4i2.946 6

Humaeni, A. (2014). Kepercayaan Kepada Kekuatan Gaib dalam Mantra Masyarakat Muslim Banten. ElHARAKAH (TERAKREDITASI), 16(1), 51. https://doi.org/10.18860/el.v16i1.2769 
Idham, I. (2019). Bahasa Mantra Sasak Tinjuan Makna Asosiatif. SASTRANESIA: Jurnal Program Studi Pendidikan Bahasa Dan Sastra Indonesia, $\quad$ 7(4). https://doi.org/10.32682/sastranesia.v7i 4.1300

Iskandar, D. (2017). Teologi, Etika, dan Islamisasi Jurnalisme. Jurnal Komunikasi, $\quad 11(1), \quad 12$. https://doi.org/10.21107/ilkom.v11i1.2 831

Iyubenu, E. A. (2015). BerhalaBerhalaWacana: Gagasan Kontekstualisasi "Sakralitas Agama" secara Produktif-Kreatif. IRCiSoD.

Kleden, I. (2018). Ilmu-Ilmu Sosial dan Teologi Kontekstual | Social Sciences and Contextual Theology. Jurnal Ledalero, $\quad 17(2), \quad 177$. https://doi.org/10.31385/jl.v17i2.150.1 77-202

Koentjaraningrat. (2000). Kebudayaan, mentalitas dan pembangunan - Google Books. Gramedia. https://www.google.co.id/books/edition /Kebudayaan_mentalitas_dan_pemban gunan/94QpZ-

x117QC?hl=id\&gbpv=1\&dq=Kebuday aan+Mentalitas+dan+Pembangunan\&p rintsec $=$ frontcover

Makmun, M. (2018). Teologi Eksklusif Era Kolonial - Potret Pemikiran KH. Ahmad Rifa'i tentang Konsep Iman. RELIGIA, 172.

https://doi.org/10.28918/religia.v21i2.1 509

Mansur, A., \& Saputra, A. (2019). Konsep Keadilan Tuhan: Studi Pemikiran Teologi Abu Mansur Al-Maturidi. AlFikra : Jurnal Ilmiah Keislaman, 17(2), 339.

https://doi.org/10.24014/af.v17i2.6373

Mansur, M. (2010). Dahsyatnya Berobat dengan Al-Fatihah. Araska.
Maryani, E. (2011). No Title. Kearifan Lokal Sebagai Sumber Pembelajaran IPS Dan Keunggulan Karakter Bangsa. Bandung: Makalah Pada Konvensi Pendidikan Nasional IPS (KONASPIPSI).

Mulyanto, N., \& Suwatno, E. (2018). Bentuk dan Fungsi Teks Mantra. Kadera Bahasa, 9(2), 75-88. https://doi.org/10.47541/kaba.v9i2.7

Mulyono, E, dkk. (2013). Belajar Hermeneutika: Dari Konfigurasi Filosofis menuju Praksis Islamic Studies. IRCiSoD.

Nurlailah, L. (2006). Kamus umum Bahasa Indonesia - Google Books. Nuansa Aliah.

https://www.google.co.id/books/edition /Kamus_umum_Bahasa_Indonesia/2L9 kAAAAMAAJ?hl=id\&gbpv=0\&bsq= Kamus Umum Indonesia

Palmer.E, R. (2003). Hermeneutika - Google Books. Pustaka Pelajar. https://www.google.co.id/books/edition /Hermeneutika/uI_rNwAACAAJ?hl=id

Poerwadarminta, W. J. . (2000). Kamus Umum Indonesia. Balai Pustaka

Ritzer, G. (2002). Teori Sosiologi. Pustaka Pelajar

Sopandi, D. A., \& Taofan, M. (2019). Konsep Teologi Inklusif Nurcholish Madjid. Jaqfi: Jurnal Aqidah Dan Filsafat Islam, 4(2), 58-92. https://doi.org/10.15575/jaqfi.v4i2.939 9

Spradley, J. P. (1979). The Ethnographic Interview - Google Books. Waveland Press.

https://www.google.co.id/books/edition /The_Ethnographic_Interview/KZ31Cw AAQBAJ?hl=id\&gbpv $=1 \& \mathrm{dq}=\mathrm{The}+\mathrm{Et}$ hnographic+Interview \&printsec $=$ frontc over

Strauss, C. L. (2000). Ras dan Sejarah Google Books. LkiS. 
https://www.google.co.id/books/edition /Ras_dan_Sejarah/fqB_DwAAQBAJ?h $\mathrm{l}=\mathrm{id} \& \mathrm{gbpv}=1 \& \mathrm{dq}=\mathrm{Ras}+\mathrm{dan}+$ Sejarah $\&$ printsec $=$ frontcover

Sunliensyar, H. H. (2018). Idu Tawa Lam Jampi: Mantra-mantra dalam Naskah Surat Incung Kerinci. Manuskripta, $8(1)$.

https://doi.org/10.33656/manuskripta.v $8 \mathrm{i} 1.100$

Tari, E. (2019). Teologi Tongkonan: Berteologi dalam Konteks Budaya Toraja. EPIGRAPHE: Jurnal Teologi Dan Pelayanan Kristiani, 2(2), 93. https://doi.org/10.33991/epigraphe.v2i2 .40

Waluyo, H. . (2010). Pengkajian dan Apresiasi Puisi. Widyasari Press

Warnke, G. (1987). Gadamer - Google Books. Polity Press. https://www.google.co.id/books/edition /_/szzdtAEACAAJ?hl=id\&sa=X\&ved= 2ahUKEwifiJPvvMnxAhXZbCsKHb7 wB1QQ7_IDMBJ6BAgYEAM

Wijayanti, K. D. (2019). Deiksis Persona dan Kekuatan Kata dalam Mantra Berbahasa Jawa. JISABDA: Jurnal Ilmiah Sastra Dan Bahasa Daerah, Serta Pengajarannya, 1(2), 47. https://doi.org/10.26877/jisabda.v1i2.4 743 